\title{
Evaluating the effect of computer simulations on secondary biology instruction: An application of Bloom's taxonomy
}

\author{
Hulya Aslan Efe and Rifat Efe* \\ Dicle University, Ziya Gokalp Education Faculty, Department of Biology Education, Diyarbakir, Turkey. \\ Accepted 14 December, 2010
}

\begin{abstract}
The purpose of this study was to examine the effects of computer simulations designed to assist $9^{\text {th }}$ grade students in learning the "cell unit". Bloom taxonomy was utilised for the design of the study and the interpretation of its findings. Participants were 91 (Male $=55$, Female=36) year nine students studying at Fatih Secondary School in Diyarbakir, Turkey. The control and experimental groups were selected at random. Students in the control group were taught using traditional teacher centred methods, where as students in experimental group were taught with the assistance of relevant computer simulations. An achievement test consisting of five questions in each of Bloom's six domains (that is, knowledge, comprehension, application, analysis, synthesis and evaluation) was given to both the control and experimental groups as a pre- and post- test. The data were analysed using SPSS 15.0 package program (t-test and ANOVA). Finding suggest that students who had access to the computer simulations scored higher on the post- tests.
\end{abstract}

Key words: Simulations, teaching/learning strategies, secondary education, improving classroom teaching, interactive learning environments.

\section{INTRODUCTION}

The rapid increase in educational computer use has led to changes in the teaching/learning process, curricula and teachers' and administrators' approaches to instruction (Loveless and Ellis, 2002). These changes in instructional techniques are shaped by the fact that computer-assisted learning increases student motivation and creates better learning environments in which rote learning is minimised and meaningful learning can occur (Renshaw and Taylor, 2000). One way of enhancing learning is to help students create models of dynamic systems by combining words with pictures (Schnotz and Bannert, 2003). This approach has assisted in the development of a special type of interactive animation: computer simulations (Nerdel and Prechtl, 2004). Computer simulations give students the opportunity to take initiative when learning about a given topic. The downside, however, is that the limit of discovery by

*Corresponding author. E- mail: rifatefe@hotmail.com. students may be determined by the limits of the simulations available for a particular topic. Therefore the success of computer simulations depends on compatibility with the curricula as well as teachers' effectiveness in utilising them (Sahin, 2006; Yilmaz, et al., 2007). Studies suggest that well-designed computer simulations have positive effects on learning, creativity, decisionmaking, communication, thinking power and initiatives (Strauss and Kinzie, 1994; Sadler et al., 1999; Stieff and Wilensky, 2003; Garcia- Lugue et al., 2004).

Simulations are classified according to the ways in which they are used. Thomas and Hooper (1991) classified simulations into four categories: experiencing, informing, reinforcing and integrating. Experiencing simulations enhance future learning and are used before the formal presentation of the material to be learned. Informing simulations are used to transmit information to the student and to supplement or replace the lecture or textbook as a means of initial formal exposure to a topic. Reinforcing simulations apply knowledge in the same context in which it was learned and are used to 
strengthen specific learning objectives. Integrating simulations help students to integrate separate facts, concepts, and principles into functional units and assimilate them with other units; they are used in situations in which several knowledge elements have been learned independently and must be applied collectively.

Simulations in science education can vary according to use. Wellington (1994) identified five types of simulation in science instruction: The first type involves repeating existing laboratory activities, such as titrations. The second type involves simulations of industrial processes, such as the manufacturing of sulphuric acid. The third type involves simulations of processes that are too dangerous, slow, fast or small for experimenting within a school environment. Examples of these processes are evolution, population growth, collisions and sub-atomic changes. The fourth type of simulation involves nonexistent entities such as ideal gases or frictionless surfaces. The fifth type can be used to teach models of theories, such as kinetic theory or the wave model of light. Incorporating simulations in science instruction increases student learning (Sambur and Can, 2007; Aydogdu, 2007; Saka and Akdeniz, 2006; Nerdel and Prechtl, 2004). The primary contribution of simulations in science education is likely their usefulness in the process of teaching. In addition, simulations can help reduce the costs associated with the chemicals and equipment necessary for laboratory experiments. They can also save time in situations in which there are few variables being examined. Finally, simulations make it easy to control variables and may even prevent traditional classroom management problems (Wellington, 1994).

Assessing student learning is an important part of the teaching/learning process, and questions are useful for triggering students thinking (Robbins, 1995). Asking questions to develop conceptual understanding can reveal students' thoughts, ideas and experiences (van Zee et al., 2000). Asking lower-level questions, on the other hand, encourage rote learning (Cepni, 2003). The cognitive domains identified in Bloom's taxonomy (Table 1) are useful reference when preparing questions designed to assess pupils' understanding of a given topic. According to Bloom's taxonomy, learning behaviours are classified into six levels (Amer, 2006): knowledge, comprehension, application, analysis, synthesis and evaluation. At the knowledge level pupils are able to recall the previously learned material; knowledge represents the lowest level of learning outcomes in the cognitive domains. Comprehension involves grasping the meaning of the material. Application refers to the ability to use learned material in new and concrete situations. This may include the application of rules, methods, concepts, principles, laws, theories, etc. Analysis involves the ability to break down material into its component parts so that its organisational structure may be understood. This may include the identification of parts, analysis of the relationships between parts, and recognition of the organisational principles involved. Synthesis is the ability to put parts together to form a new whole. Evaluation refers to the ability to judge the value of the material (example, a statement, novel, poem or research report) for a given purpose. Table 1 illustrates the different cognitive domains of Bloom's taxonomy.

Studies of Bloom's taxonomy have usually investigated the level of questions commonly asked on exams and in textbooks. A study by Efe and Temelli (2003) revealed that the nature of biology questions in university entrance examinations is changing from lower-level to higher-level. According to Koksal (2004), however, the percentage of lower-level questions is still too high $(73 \%$ of biology questions). The similar nature of the questions also applies to chemistry and physics: studies have revealed a need for the questions probing higher levels of the cognitive domains including analysis, synthesis and evaluation (Ozmen, 2005; Cepni et al., 2003).

The present study utilised Bloom's cognitive domains as a reference point in order to investigate the effect of computer simulations on learning the "cell unit" in a secondary biology course. The purpose of the study was to answer the following research questions:

1. When the cognitive domains of Bloom's taxonomy are considered, is there a difference in students' achievement when learning the "cell unit" with the help of computer simulations and learning in the traditional method?

2. Are any gender differences in achievement found when comparing the two methods of instruction?

\section{MATERIALS AND METHODS}

\section{Participants}

Participants were 91 (Male $=55$, Female $=36$ ) year nine students from two randomly selected classrooms at the Fatih Secondary School in Diyarbakir, Turkey, in 2008 to 2009 academic year. The experimental group consist of 52 students (Male $=30$, Female $=22$ ) and the control group consist of 39 students $(\mathrm{Male}=25$, Female $=$ 14).

\section{Data collection instruments}

A pre-test and a post-test were used to assess achievement. Five questions from each cognitive domain of Bloom's taxonomy were included on the test. Twenty-one questions were multiple choice and nine questions were open-ended. The tests were prepared with the help of two biologists from an education faculty and one biology teacher from a secondary school. The reliability of the multiplechoice questions was assessed by using the split-half method. Right answers were given 1 point and wrong answers were given 0 points. The Spearman- Brown formula was used to measure reliability coefficients. For half of test, $r=0.634$, for the whole test, $r=$ 0.780. Rubrics were used to score open-ended questions (Hillsborough, 2009). Responses to each question were awarded either 3, 2, 1 or 0 points. A 3-point response was reasonably correct, clear and satisfactory. A 2- point response had minor omissions and/or some incorrect or irrelevant information. A 1-point response included some correct information but was mostly either incorrect or irrelevant. A 0-point response was either incorrect, 
Table1. Cognitive domains of Bloom's taxonomy and sample questions.

\begin{tabular}{|c|c|c|}
\hline Cognitive level & Features of cognitive level & Sample question \\
\hline & Recall data or information. & \\
\hline Knowledge & $\begin{array}{l}\text { Key words: defines, describes, identifies, knows, } \\
\text { labels, lists, matches, names, outlines, recalls, } \\
\text { recognises, reproduces, selects, states. }\end{array}$ & Identify the functions of the ribosome. \\
\hline & $\begin{array}{l}\text { Understand the meaning, translation, interpolation, } \\
\text { and interpretation of instructions and problems. } \\
\text { State a problem in one's own words. }\end{array}$ & \\
\hline Comprehension & $\begin{array}{l}\text { Key words: comprehends converts, defends, } \\
\text { distinguishes estimates, explains, extends, } \\
\text { generalises, gives examples, infers, interprets } \\
\text { paraphrases, predicts rewrites, summarises, and } \\
\text { translates. }\end{array}$ & $\begin{array}{l}\text { Which part of our body has cells } \\
\text { containing high quantities of } \\
\text { mitochondria? }\end{array}$ \\
\hline Application & $\begin{array}{l}\text { Use a concept in a new situation or unprompted } \\
\text { use of an abstraction. Apply what was learned in } \\
\text { the classroom to novel situations in the work-place. } \\
\text { Key words: applies, changes, computes, } \\
\text { constructs, demonstrates, discovers, manipulates, } \\
\text { modifies, operates, predicts, prepares, produces, } \\
\text { relates, shows, solves, uses. }\end{array}$ & $\begin{array}{l}\text { How many tetrads are produced in a } \\
\text { mother reproductive cell with } 2 n=64 \\
\text { chromosomes? }\end{array}$ \\
\hline Analysis & $\begin{array}{l}\text { Separates material or concepts into component } \\
\text { parts so that its organisational structure may be } \\
\text { understood. Distinguishes between facts and } \\
\text { inferences. } \\
\text { Key words: analyses, breaks down, compares, } \\
\text { contrasts, diagrams, deconstructs, differentiates, } \\
\text { discriminates, distinguishes, identifies, illustrates, } \\
\text { infers, outlines, relates, selects, separates. }\end{array}$ & $\begin{array}{l}\text { Explain the reasons why a basic } \\
\text { circulatory system is sufficient for } \\
\text { insects? }\end{array}$ \\
\hline Synthesis & $\begin{array}{l}\text { Builds a structure or pattern from diverse elements. } \\
\text { Put parts together to form a whole, with emphasis } \\
\text { on creating a new meaning or structure. } \\
\text { Key words: categorises, combines, compiles, } \\
\text { composes, creates, devises, designs, explains, } \\
\text { generates, modifies, organises, plans, rearranges, } \\
\text { reconstructs, relates, reorganises, revises, } \\
\text { rewrites, summarises, tells, writes. }\end{array}$ & $\begin{array}{l}\text { Develop a project and come up with } \\
\text { solutions to protect the Turkey's } \\
\text { biological richness. }\end{array}$ \\
\hline \multirow{5}{*}{ Evaluation } & \multirow{5}{*}{$\begin{array}{l}\text { Make judgments about the value of ideas or } \\
\text { materials. } \\
\text { Key words: appraises, compares, concludes, } \\
\text { contrasts, criticises, critiques, defends, describes, } \\
\text { discriminates, evaluates, explains, interprets, } \\
\text { justifies, relates, summarises, supports. }\end{array}$} & $\begin{array}{l}\text { "Protists that reproduce sexually have } \\
\text { higher chances of adapting to } \\
\text { changing environmental conditions in } \\
\text { comparison with protists that } \\
\text { reproduce asexually." Which of the } \\
\text { following is the evidence of this } \\
\text { generalisation? }\end{array}$ \\
\hline & & $\begin{array}{l}\text { (A)The number of individuals not } \\
\text { rising in asexual reproduction. } \\
\text { B)Self-replication of DNA in asexual } \\
\text { reproduction }\end{array}$ \\
\hline & & $\begin{array}{l}\text { C) The formation of new combinations } \\
\text { of genes in sexual reproduction }\end{array}$ \\
\hline & & $\begin{array}{l}\text { D) Sexual reproduction is found in } \\
\text { bacteria }\end{array}$ \\
\hline & & $\begin{array}{l}\text { E)The asexual reproduction of } \\
\text { protists is frequently observed }\end{array}$ \\
\hline
\end{tabular}


Table 2. Comparison the control and experimental groups' pre- test results according to Bloom's taxonomy.

\begin{tabular}{|c|c|c|c|c|c|}
\hline Level of Bloom's taxonomy & Group & $\mathbf{N}$ & $\overline{\bar{X}}$ & SS & Result \\
\hline \multirow{2}{*}{ Knowledge } & Control & 39 & 0.3538 & 0.20241 & \multirow{2}{*}{$\begin{array}{c}\mathrm{t}: 0.176, \\
\text { Sig:0.861 } \\
\mathrm{p}>0.05\end{array}$} \\
\hline & Experimental & 52 & 0.3462 & 0.21001 & \\
\hline \multirow[t]{2}{*}{ Comprehension } & Control & 39 & 0.2667 & 0.16114 & \multirow{2}{*}{$\begin{array}{c}\mathrm{t}:-0.889, \\
\text { Sig:0.376 } \\
\mathrm{p}>0.05\end{array}$} \\
\hline & Experimental & 52 & 0.3000 & 0.18787 & \\
\hline \multirow{2}{*}{ Application } & Control & 39 & 0.1333 & 0.14749 & \multirow{2}{*}{$\begin{array}{c}\mathrm{t}:-0.037, \\
\text { Sig:0.971 } \\
\mathrm{p}>0.05\end{array}$} \\
\hline & Experimental & 52 & 0.1346 & 0.17588 & \\
\hline \multirow{2}{*}{ Analysis } & Control & 39 & 0.3487 & 0.25013 & \multirow{2}{*}{$\begin{array}{c}\mathrm{t}:-0.168, \\
\text { Sig:0.867 } \\
\mathrm{p}>0.05\end{array}$} \\
\hline & Experimental & 52 & 0.3577 & 0.25464 & \\
\hline \multirow{2}{*}{ Synthesis } & Control & 39 & 0.3385 & 0.25196 & \multirow{2}{*}{$\begin{array}{c}\text { t: } 0.236, \\
\text { Sig:0.261 } \\
p>0.05\end{array}$} \\
\hline & Experimental & 52 & 0.2692 & 0.31407 & \\
\hline \multirow{2}{*}{ Evaluation } & Control & 39 & 0.2769 & 0.26204 & \multirow{2}{*}{$\begin{array}{c}\text { t: } 0.689, \\
\text { Sig:0.615 } \\
p>0.05\end{array}$} \\
\hline & Experimental & 52 & 0.2500 & 0.24375 & \\
\hline
\end{tabular}

irrelevant or inappropriate (although an attempt was made to answer the question). Cronbach's alpha for the reliability of openended question scores was 0.754 .

\section{Data analysis}

The data were analysed by using SPSS 15.0 package program at the significance level of 0.05 . Independent samples t-tests were used to compare the experimental and control groups' achievement test results. Differences between the groups pre- and post- test results were calculated using paired samples t-tests. Differences between genders were calculated using independent samples ttest.

\section{RESULTS}

\section{Between group comparisons}

\section{Pre-test}

No statistically significant differences between pre-test scores of students in the experimental and control groups were found (Table 2).

It is evident from the Table 2 that students in both groups were similarly successful in answering pre-test questions from each of Bloom's cognitive domains. A comparison of means revealed that students in the control group were slightly better at answering pre-test questions requiring the knowledge, synthesis and evaluation domains. In comparison, students in the experimental group were slightly better at answering questions requiring the comprehension, application and analysis levels of Bloom's taxonomy. It is important to note, however, that these differences are not statistically significant ( $p>0.05)$.

A comparison of achievement test scores according to gender and the six levels of Bloom's taxonomy did not reveal any statistically significant differences (Table 3 ).

A comparison of pre-test means revealed that male students were better at answering knowledge, application, analysis, and evaluation questions, whereas female students were slightly better at answering comprehension and synthesis questions. It is important to note, however, that only the difference for application questions was statistically significant $(p<0.05)$. This finding suggests that male students were better at answering questions at the application level of Bloom's taxonomy. However, it is unlikely that this difference is systematic, as the post-test results do not show the same pattern.

\section{Post-test}

The analysis of post-test results revealed that students taught with help of computer simulations were more 
Table 3. Comparison of students' pre- test results according to gender.

\begin{tabular}{|c|c|c|c|c|c|}
\hline Level of Bloom's taxonomy & Gender & $\mathbf{N}$ & $\overline{\bar{X}}$ & SS & Result \\
\hline \multirow[b]{2}{*}{ Knowledge } & Male & 55 & 0.3750 & 0.18315 & $\mathrm{t}: 1.509$ \\
\hline & Female & 36 & 0.3086 & 0.23436 & $\begin{array}{l}\text { Sig:0.135 } \\
\text { p>.05 }\end{array}$ \\
\hline \multirow[b]{2}{*}{ Comprehension } & Male & 55 & 0.2607 & 0.16145 & $\mathrm{t}: .-1.725$ \\
\hline & Female & 36 & 0.3257 & 0.19455 & $\begin{array}{c}\text { Sig:0.088 } \\
p>0.05\end{array}$ \\
\hline \multirow[b]{2}{*}{ Application } & Male & 55 & 0.1714 & 0.16372 & t: .2.867, \\
\hline & Female & 36 & 0.0743 & 0.14621 & $\begin{array}{c}\text { Sig:0.005 } \\
p<0.05\end{array}$ \\
\hline \multirow[b]{2}{*}{ Analysis } & Male & 55 & 0.3643 & 0.25040 & t: 0.499 \\
\hline & Female & 36 & 0.3371 & 0.25563 & $\begin{array}{c}\text { Sig:0.619 } \\
p>0.05\end{array}$ \\
\hline \multirow[b]{2}{*}{ Synthesis } & Male & 55 & 0.2964 & 0.30269 & $\mathrm{t}:-0.102$ \\
\hline & Female & 36 & 0.3029 & 0.27169 & $\begin{array}{c}\text { Sig:0.919 } \\
p>0.05\end{array}$ \\
\hline \multirow{2}{*}{ Evaluation } & Male & 55 & 0.2679 & 0.26499 & $\mathrm{t}:-0.303$ \\
\hline & Female & 36 & 0.2514 & 0.22928 & $\begin{array}{c}\text { Sig:0.763 } \\
p>0.05\end{array}$ \\
\hline
\end{tabular}

successful at answering questions related to the cell unit when compared to students taught with traditional methods.

When the cognitive domains of Bloom's taxonomy are considered (Table 4), statistically significant differences in students' responses to questions in the knowledge, comprehension, application, analysis, synthesis and evaluation levels are revealed. These differences are also apparent in the mean scores. On each of the six levels, students taught with computer simulations scored higher than students taught with traditional methods.

Findings (Table 5) do not reveal any statistically significant differences between male and female students' performance on the achievement post test $(p>0.05)$. A comparison of mean values indicates that female students outperform male students when answering questions in comprehension, application, analysis, synthesis and evaluation levels. Male students, on the other hand, are slightly more successful at answering post-test questions at the knowledge level. Although these differences are not statistically significant, the performance of female students is interesting given that male are typically expected to spend more time using computers and computer games. It is therefore reasonable to expect male students to benefit more from computer-supported learning. The results obtained from this study, however, show that female students do not lag behind their male counterparts in terms of making use of computers to aid their learning.

\section{Within group comparisons}

\section{Control group}

The control and experimental groups' pre- and post-tests were analysed to determine whether there were any significant differences in students' performance on the achievement tests. t-test results (Table 6) revealed no significant difference between the control group's achievement on pre- and post-tests. As Table 6 illustrates only statistically significant difference appears at the application level of Bloom's cognitive domains.

Statistically significant differences were not observed for any of the other five levels (that is, knowledge, comprehension, analysis, synthesis and evaluation). When raw mean scores are analysed, it is interesting to observe that the control group performed better on post-test questions related to the first four levels of Bloom's taxonomy yet they were less successful on question from the last two levels (synthesis and evaluation).

\section{Experimental group}

Analysis of the experimental group's pre- and post-test 
Table 4. Comparison of the control and experimental groups' post-test results according to Bloom's taxonomy.

\begin{tabular}{|c|c|c|c|c|c|}
\hline Level of Bloom's taxonomy & Group & $\mathbf{N}$ & $\overline{\bar{X}}$ & SS & Result \\
\hline \multirow{2}{*}{ Knowledge } & Control & 39 & 0.3846 & 0.19673 & $\mathrm{t}:-6.367$ \\
\hline & Experimental & 52 & 0.6808 & 0.23518 & $\begin{array}{c}\text { Sig: } 0.000 \\
p<0.01\end{array}$ \\
\hline \multirow{2}{*}{ Comprehension } & Control & 39 & 0.2923 & 0.17073 & $\mathrm{t}:-5.039$ \\
\hline & Experimental & 52 & 0.5231 & 0.24464 & $\begin{array}{c}\text { Sig:0.000 } \\
p<0.01\end{array}$ \\
\hline \multirow{2}{*}{ Application } & Control & 39 & 0.2051 & 0.18057 & t:-5.472 \\
\hline & Experimental & 52 & 0.4577 & 0.24201 & $\begin{array}{c}\text { Sig:0.000 } \\
p<.001\end{array}$ \\
\hline \multirow{2}{*}{ Analysis } & Control & 39 & 0.4821 & 0.25841 & $\mathrm{t}:-0.975$ \\
\hline & Experimental & 52 & 0.7038 & 0.26713 & $\begin{array}{c}\text { Sig:0.000 } \\
p<0.01\end{array}$ \\
\hline \multirow[b]{2}{*}{ Synthesis } & Control & 39 & 0.2103 & 0.23819 & $\mathrm{t}:-5.883$ \\
\hline & Experimental & 52 & 0.6115 & 0.37241 & $\begin{array}{c}\text { Sig:0.000 } \\
p<0.01\end{array}$ \\
\hline \multirow{2}{*}{ Evaluation } & Control & 39 & 0.5487 & 0.21383 & $\mathrm{t}:-6.321$ \\
\hline & Experimental & 52 & 0.9731 & 0.37579 & $\begin{array}{c}\text { Sig:0.000 } \\
p<0.01\end{array}$ \\
\hline
\end{tabular}

results revealed statistically significant $(p<0.05)$ differences between scores on the two tests (Table 7). On each of the six levels of Bloom's taxonomy, students' post-test scores were significantly higher than their pretest scores.

The mean scores in Table 7 indicate that the greatest pre- and post-test improvement occurred in the higher levels of Bloom's taxonomy, including analysis, synthesis and evaluation.

\section{DISCUSSIONS}

Studies on the effectiveness of teaching methods have generally focused on comparing a favoured teaching method with traditional teaching methods that incorporate active teacher involvement. In the present study, students' retention in the secondary cell unit was investigated by comparing traditional instruction with instruction involving computer simulations. Previous studies in primary, secondary and higher education have reported the effectiveness of computer assisted learning (Kacar and Dogan, 2007; Aydogdu, 2006; Gonen et al., 2006; Akgun, 2005; Nerdel and Precthl, 2004; Demircioglu and Geban, 1996). The cell unit is considered foundational for all secondary biology because learning about the cell and its functions leads to greater understanding of other biology topics. Teaching a topic that includes cell structure, functions of different organelles and cell division can be challenging, as most students in traditional learning environments are likely to find it difficult to concretely visualise and understand what is being taught. However, using computer simulations to teach cell topics helps students to visualise the ways in which cell parts function. For example, a student can observe how oxygen, food and water penetrate the cell membrane, how waste products are expelled, and how harmful substances are kept out. Through computer simulations, students can observe how active and passive transportation work; they can try to increase or decrease the concentration of different substances inside or outside of the cell membrane and see the results for themselves. The present study investigated whether using computer simulations to teach the cell unit would have an effect on learning. Cognitive domains of Bloom's taxonomy were used to examine the level of student achievement. Results indicate that students who were taught with help of computer simulations were more successful at all six cognitive domains, including knowledge, comprehension, application, analysis, synthesis and evaluation. This was particularly true of development at the levels that required higher-order thinking skills 
Table 5. Comparison of students' post- test results according to gender.

\begin{tabular}{|c|c|c|c|c|c|}
\hline Level of Bloom's taxonomy & Gender & $\mathbf{N}$ & $\overline{\bar{X}}$ & SS & Result \\
\hline \multirow{2}{*}{ Knowledge } & Male & 55 & 0.5556 & 0.26255 & $\mathrm{t}: 0.074$ \\
\hline & Female & 36 & 0.5514 & 0.26835 & $\begin{array}{c}\text { Sig:0.941 } \\
p>0.05\end{array}$ \\
\hline \multirow{2}{*}{ Comprehension } & Male & 55 & 0.4185 & 0.25850 & $\mathrm{t}:-0.266$ \\
\hline & Female & 36 & 0.4324 & 0.22367 & $\begin{array}{c}\text { Sig:0.791 } \\
p>0.05\end{array}$ \\
\hline \multirow[t]{2}{*}{ Application } & Male & 55 & 0.3185 & 0.25923 & $\mathrm{t}:-1.431$ \\
\hline & Female & 36 & 0.3946 & 0.23327 & $\begin{array}{c}\text { Sig:0.156 } \\
p>0.05\end{array}$ \\
\hline \multirow{2}{*}{ Analysis } & Male & 55 & 0.5889 & 0.27859 & $\mathrm{t}:-0.805$ \\
\hline & Female & 36 & 0.6378 & 0.29378 & $\begin{array}{c}\text { Sig: } 0.423 \\
p>0.05\end{array}$ \\
\hline \multirow{2}{*}{ Synthesis } & Male & 55 & 0.4000 & 0.35181 & $\mathrm{t}:-1.211$ \\
\hline & Female & 36 & 0.4973 & 0.40994 & $\begin{array}{c}\text { Sig:0.229 } \\
p>0.05\end{array}$ \\
\hline \multirow[t]{2}{*}{ Evaluation } & Male & 55 & 0.7519 & 0.34518 & $\mathrm{t}:-1.198$ \\
\hline & Female & 36 & 0.8486 & 0.42270 & $\begin{array}{c}\text { Sig:0.234 } \\
p>0.05\end{array}$ \\
\hline
\end{tabular}

(analysis, synthesis and evaluation). Previous studies have reported that computer simulations help students to develop thinking and interpretation skills and, as a result, they develop higher-order thinking skills (Ozmen and Kolomuc, 2004). The present study supports this finding (Pektas et al., 2006; Saka and Akdeniz, 2006; Akcay et al., 2005; Huppert et al., 2002; Guler and Saglam, 2002) by suggesting that computer simulations result in better learning outcomes in comparison with traditional teachercentred learning environments. One reasons for the success of the students in the experimental group is probably the fact that simulations can help students to visualise processes that seem abstract and complex such as the fluid mosaic model, transportation in and out of the cell membrane and functions of the organelles. Reiber and Noah (2008) suggest that using visual instruments in learning environments is important and extremely valuable as it provides opportunities for students to discuss what they are observing. This, in turn, can help to develop their self-confidence. Using simulations to teach cell topics has a number of advantages. It is simple in terms of the complexity of laboratory experiments and inexpensive when considering that most secondary science classrooms have computers. Simulations are safe in comparison to using chemicals and other potentially dangerous materials and they are practical in terms of administration skills. They are also often less time consuming and, unlike laboratory experiments, simulations can be played back as many times as necessary (Sahin, 2006). In addition to these important contributions studies of science education often report positive effects from computer-assisted learning in terms of academic achievement (Cekbas et al., 2003; Gance, 2002). Studies also suggest that enriching learning environments with simulations increases students' motivation to learn (Winberg and Headman, 2008). Many studies have found a link between positive motivation and a quality learning environment (Chin and Brown, 2000; Covington, 2000, Hynd et al., 2000).

Despite the reported benefits, however, Wellington (1994) identified five dangers associated with using computer simulations in science education. Firstly, simulations give pupils the impression that variables in a physical process can be easily, equally and independently controlled. Secondly, every simulation is based on a certain model of reality. Users are only able to manipulate factors and variables within the model; they cannot tamper with the model itself. Thirdly, any model is an idealisation of reality; it ignores certain features in order to concentrate on others. Fourthly, pupils are almost certain to confuse the programmer's model of reality with reality itself. Fifth, the idealisation involved in modelling is doubly dangerous in simulations involving a model of a model. For example, a simulation of the fluid 
Table 6. Comparison of the control group's pre- and post-test results according to Bloom's taxonomy.

\begin{tabular}{|c|c|c|c|c|c|}
\hline Level of Bloom's taxonomy & Test & $\mathbf{N}$ & $\overline{\bar{X}}$ & SD & Result \\
\hline \multirow{2}{*}{ Knowledge } & Pre-test & 39 & 0.3538 & 0.20241 & $\mathrm{t}:-0.635$ \\
\hline & Post-test & 39 & 0.3795 & 0.19355 & $\begin{array}{c}\text { Sig:0.529 } \\
p>0.05\end{array}$ \\
\hline \multirow{2}{*}{ Comprehension } & Pre-test & 39 & 0.3590 & 0.18456 & $\mathrm{t}: 1.803$ \\
\hline & Post-test & 39 & 0.3623 & 0.17073 & $\begin{array}{c}\text { Sig:0.079 } \\
p>0.05\end{array}$ \\
\hline \multirow[t]{2}{*}{ Application } & Pre-test & 39 & 0.1282 & 0.14133 & $\mathrm{t}:-2.252$ \\
\hline & Post-test & 39 & 0.2051 & 0.18057 & $\begin{array}{l}\text { Sig:0.03 } \\
p<0.05\end{array}$ \\
\hline \multirow{2}{*}{ Analysis } & Pre-test & 39 & 0.4513 & 0.25841 & $\mathrm{t}: 0.875$ \\
\hline & Post-test & 39 & 0.5077 & 0.25067 & $\begin{array}{c}\text { Sig:0.387 } \\
p>0.05\end{array}$ \\
\hline \multirow[b]{2}{*}{ Synthesis } & Pre-test & 39 & 0.3385 & 0.25196 & $\mathrm{t}: 1.411$ \\
\hline & Post-test & 39 & 0.2718 & 0.25747 & $\begin{array}{c}\text { Sig:0.166 } \\
p>0.05\end{array}$ \\
\hline \multirow[t]{2}{*}{ Evaluation } & Pre-test & 39 & 0.2769 & 0.26204 & $\mathrm{t}: 1.389$ \\
\hline & Post-test & 39 & 0.2051 & 0.24056 & $\begin{array}{c}\text { Sig: } 0.173 \\
p>0.05\end{array}$ \\
\hline
\end{tabular}

Table 7. Comparison of the experimental group's pre- and post-test results according to Bloom's taxonomy.

\begin{tabular}{|c|c|c|c|c|c|}
\hline Level of Bloom's taxonomy & Test & $\mathbf{N}$ & $\bar{X}$ & SD & Result \\
\hline \multirow{2}{*}{ Knowledge } & Pre-test & 52 & 0.3500 & 0.22007 & $\mathrm{t}:-8.913$ \\
\hline & Post-test & 52 & 0.6846 & 0.23211 & $\begin{array}{c}\text { Sig:0.000 } \\
P<0.001\end{array}$ \\
\hline \multirow{2}{*}{ Comprehension } & Pre-test & 52 & 0.2962 & 0.18783 & $\mathrm{t}:-5.407$ \\
\hline & Post-test & 52 & 0.5269 & 0.24424 & $\begin{array}{c}\text { Sig:0.000 } \\
P<0.01\end{array}$ \\
\hline \multirow{2}{*}{ Application } & Pre-test & 52 & 0.1423 & 0.17861 & $\mathrm{t}:-8.281$ \\
\hline & Post-test & 52 & 0.4615 & 0.24266 & $\begin{array}{c}\text { Sig:0.000 } \\
P<0.01\end{array}$ \\
\hline \multirow{2}{*}{ Analysis } & Pre-test & 52 & 0.3615 & 0.25372 & $t:-6.350$ \\
\hline & Post-test & 52 & 0.7038 & 0.26713 & $\begin{array}{c}\text { Sig:0.000 } \\
P<0.01\end{array}$ \\
\hline \multirow[b]{2}{*}{ Synthesis } & Pre-test & 52 & 0.2692 & 0.31407 & $\mathrm{t}:-7.163$ \\
\hline & Post-test & 52 & 0.7269 & 0.45336 & $\begin{array}{c}\text { Sig:0.000 } \\
p<0.01\end{array}$ \\
\hline \multirow{2}{*}{ Evaluation } & Pre-test & 52 & 0.2500 & 0.24375 & $\mathrm{t}:-5.888$ \\
\hline & Post-test & 52 & 0.6077 & 0.37565 & $\begin{array}{c}\text { Sig:0.000 } \\
P<0.01\end{array}$ \\
\hline
\end{tabular}


mosaic model is itself based on a model of reality.

\section{Conclusions}

The present study investigated the effects of computer simulations on learning about cells in a secondary biology class. The cognitive domains established in Bloom's taxonomy were used to categorise questions for the pretest and post-test that were given to both the control and experimental groups. Findings revealed that students who were taught with the help of computer simulations made statistically significant improvements in their test scores on all six levels (knowledge, comprehension, application, analysis, synthesis and evaluation) of Bloom's taxonomy. It can therefore be concluded that the use of computer simulations to teach cell-related topics in secondary curricula will help students to visualise processes that seem abstract and complex (example, fluid mosaic model, transportation in and out of the cell membrane, functions of the organelles). In addition to enhancing the ability of students to learn complex cell processes, computer simulations can also help teachers to eliminate the difficult and time-consuming practicalities associated with laboratory experiments.

\section{REFERENCES}

Akcay S, Aydoğdu M, Yıdırım Hİ, Şensoy Ö (2005). Fen Eğitiminde Illköğretim 6. Sınıflarda Çiçekli Bitkiler Konusunun Öğretiminde Bilgisayar Destekli Öğretimin Öğrenci Başarısına Etkisi. Kastamonu Eğitim Dergisi., 13(1): 103-116.

Amer A (2006). Reflections on Bloom's Revised Taxonomy. Electron. J. Res. Educ. Psychol., 4(8): 213-230

Aydoğdu C (2006). Bilgisayar Destekli Kimyasal Bağ Öğretiminin Öğrenci Başarısına Etkisi. AÜ . Bayburt Eğitim Fakültesi Dergisi., 1(1): 80-90

Çekbaş Y, Yakar H, Yıldırım B, Savran A (2003). Bilgisayar Destekli Eğitimin Öğrenciler Üzerine Etkisi. The Turkish Online J. Educ. Technol., 2(4).

Çepni S, Özsevgeç T, Gökdere M (2003). Bilişsel Gelişim ve Formal Operasyon Dönem Özelliklerine göre OSS Fizik Ve Lise Fizik Sorularının İncelenmesi. Milli Eğitim Dergisi., 157: 30-39.

Chin C, Brown DE (2000). Learninig in Science: A Comparison of Deep and Surface Approaches, J. Res. Sci. Teaching., 37(2): 109-138.

Covington MV (2000). Goal Theory, Motivation and School Achievement: An Integrative Review. Ann. Rev. Psychol., 51(1): 171200.

Demircioğlu H, Geban Ö (1996). Fen Bilgisi Öğretiminde Bilgisayar Destekli Öğretim ve Geleneksel Problem Çözme Etkinliklerinin Ders Başarısı Bakımından Karşılaştııılması. Hacettepe Üniversitesi Eğitim Fakültesi Dergisi., 12: 183-185.

Efe N, Temelli A (2003). 1999-2000-2001 ÖSS Biyoloji Sorularının Düzey ve İçerik Yönünden Değerlendirilmesi. Kastamonu Eğitim Dergisi., 11(1): 105-114.

Gance S (2002). Are Constructivism and Computer-Based Learning Envoriments Incompatible? J. Assoc. Hist. Comput., 5(1): 12.

Garcia-Luque E, Ortega T, Forja JM, Gomez-Perra A (2004). Using a Laboratuary Simulator in the Teaching and Study of Chemical Processes in Estuarine System. Comput. Educ., 43(1-2): 81-90.

Gönen S, Kocakaya S, Inan C (2006). The Effect of the Computer Assisted Teachıng and 7E Model of the Constructıvist Learnıng Methods on the Achievements and Attitudes of High School Students. The Turkish Online J. Educ. Technol., 5(4).
Güler MH, Sağlam N (2002). Biyoloji Öğretiminde Bilgisayar Destekli Öğretimin ve Çalışma Yapraklarının Öğrencilerin Başarısı ve Bilgisayara Karsı Tutumlarına Etkileri. Hacettepe Üniversitesi Eğitim Fakültesi Dergisi., 23: 117-126.

http://www.hillsborough.k12.nj.us/139210101316759720/lib/1392101013 16759720/BiologyEOCspecs.doc

Huppert J, Michal Lomask S, Lazarowitz R (2002). Computer simulations in the high school: students' cognitive stages, science process skills and academic achievement in microbiology. Int. J. Sci. Educ., 24(8): 803-821.

Hynd C, Holschuh J, Nist S (2000). Learninig Complex Sciencetific Information: Motivation Theory and its Relation to Student Perceptions. Reading Writing Q., 16(1): 23-35.

Kaçar AÖ, Doğan N (2007). Okul Öncesi Eğitimde Bilgisayar Destekli Öğretimin Rolü. Akademik Bilişim. Dumlupınar Üniversitesi. 31 Ocak2 Şubat.

Köksal EA, (2004). 1998-2001 Orta Öğretim Kurumları Öğrenci Seçme ve Yerleştirme Sınavları'nda Çıkan Biyoloji Sorularının İçerik Analizi. XIII. Ulusal Eğitim Bilimleri Kurultayı. 6-9 Temmuz. İnönü Üniversitesi Eğitim Fakültesi. Malatya.

Loveless A, Ellis V (2002). Information and Communication Technologies, Pedagogy and the Curriculum. Educ. Inf. Technol., 7(1): 81-83.

Nerdel C, Prechtl H (2004). Learning Complex Systems with Simulations in Science Education. http:/www.iwmkmrc.de/workshops/SIM2004/pdf_files/Nerdel_et_al.pdf.

Ozmen H (2005). 1990-2005 OSS Sınavlarındaki Kimya Sorularının Konu Alanlarına ve Bloom Taksonomisi'ne Gore İncelenmesi. Eurasian J. Educ. Res., 21: 187-199.

Ozmen H, Kolomuç A (2004). Bilgisayarlı Öğretimin Çözeltiler Konusundaki Öğrenci Başarısına Etkisi. Kastamonu Eğitim Dergisi., 12(1): 57-68.

Pektaş M, Özmen L, Solak K (2006). Bilgisayar Destekli Öğretimin Fen Bilgisi Öğretmen Adaylarının Sindirim Sistemi ve Boşaltım Sistemi Konularını Öğrenmeleri Üzerine Etkisi. Kastamonu Eğitim Dergisi., 14 (2): 465-472.

Renshaw CE, Taylor HA (2000). The Educational Effectiveness of Computer-Based Instruction. Comput. Geosci., 26(6): 677-682.

Rieber LP, Noah D (2008). Games, Simulations and Visual Metaphorr in Education: Antagonism between Enjoyment and Learning. Educ. Media Int., 45(2): 77-92.

Robbins A (1995). İçindeki Devi Uyandır. Çev. Belkıs Çorakçı (Dişbudak). İstanbul. İnkılap Yayınevi.

Sadler PM, Whitney CA, Shore L, Deutsch F (1999). Visualization and Representation of Physical Systems: Wavemaker as an Aid to Conceptualizing Wave Phenomena. J. Sci. Educ. Technol., 8(3): 197209.

Sahin S (2006). Computer Simulations in Science Education: Implication for Distance Education. Turkish Online J. Dist. Educ., 7(4): 132-146.

Saka A, Akdeniz AR (2006). Genetik Konusunda Bilgisayar Destekli Materyal Geliştirilmesi ve 5E Modeline göre Uygulanması. The Turkish Online J. Educ. Technol., 5(1).

Sambur E, Can Ş (2007). Web Destekli Laboratuvar Öğretiminin Fen Bilgisi Öğretmen Adaylarının Fen Laboratuvarı ve Bilgisayar Tutumları Üzerine Etkisi. XVI. Ulusal Eğitim Bilimleri Kongresi. 5-7 Eylül, Tokat.

Schnotz W, Bannert M (2003). Construction and Interference in Learninig from Multiple Representation. Learning and Instruct., 13: 141-156.

Stieff M, Wilensky U (2003). Connected Chemistry-Incorporating Interactive Simulations into the Chemistry Classroom. J. Sci. Educ. Technol., 12, 280-302.

Strauss R, Kinzie MB (1994). Student Achievement and Attitudes in a Pilot Study Comparing an Interactive Videodisc Simulation to Conventional Dissection. Am. Biol. Teacher., 56: 398-402.

Thomas R, Hooper E (1991). Simulations: An opportunity we are missing. J. Res. Comput. Educ., 23: 497-513.

Van Zee EH, Iwasyk M, Kurose A, Simpson D, Wild J (2001). Students and Teacher Qestioning during Conversations about Science. J. Res. Sci. Teaching., 38(2): 159-190.

Wellington J (1994). Secondary Science: Contemporary Issues and Practical Approaches, Newyork: Routledge. 
Winberg TM, Headman L (2007). Student Attitudes Toward Learning, Level of Pre-Knowledge and Instruction Type in a ComputerSimulation: Effects on Flow Experiences and Perceived Learning Outcomes. Springer Sci. Bus. Media BV., 36: 269-287.
Yılmaz Ö, Akıncı TÇ, Sevindik T (2007). Simülasyon Programlarının Aydınlatma Eğitimindeki Önemi ve Örnek bir Uygulama. E,J New World Sci. Acad. Nat. Appl. Sci., 2(3): 208-213. 